\title{
DEVELOPMENT OF PRE-TURBO CATALYST FOR NATURAL GAS ENGINES
}

\author{
Thierry Leprince, Joe Aleixo, Kamal Chowdhury, Mojghan Naseri, Shazam Williams \\ DCL International Inc. \\ P.O. Box 90, Concord, Ontario, Canada, L4K 1 B2
}

\begin{abstract}
Distributed power generation is an efficient method for reducing $\mathrm{CO}_{2}$ emissions through the elimination of transmission losses. Co-generation has similar benefits with higher thermal efficiency. Natural gas engines are very popular for these applications. Unfortunately, these engines emit significant levels of methane, which is a greenhouse gas. Reduction of methane emissions would greatly improve the environment and provide greenhouse gas emissions credits.
\end{abstract}

The exhaust temperature downstream of the turbocharger in a natural gas engine is typically below $500^{\circ} \mathrm{C}$. At these temperatures, methane is difficult to oxidize with current oxidation catalysts. It would be a much better option to install the oxidation catalyst before the turbocharger where temperatures are $100-150^{\circ} \mathrm{C}$ higher. Pressures upstream of the turbocharger are higher than downstream and also affect catalyst conversion efficiencies.

Misfiring events are common in natural gas engines. During misfiring events, the catalyst will see a sudden increase in hydrocarbon (methane). When this pulse of hydrocarbon hits the catalyst, it will be oxidized and generate a large exotherm which could lead to catalyst failure (mechanical and/or chemical). This issue is critical for a pre-turbo catalyst:

1) Mechanical failure of the catalyst could lead to catastrophic turbocharger failure, a result of the turbine blades being damaged.

2) Misfiring with catalyst installed before the turbocharger is more likely to ignite the methane pulse because of the higher temperatures in this location. High exotherms from ignition could negatively affect catalyst performance.

Through careful catalyst design, one can minimize this risk and this paper will address these issues.

\section{INTRODUCTION}

Lean-burn natural gas engines are very popular for applications involving power generation and co-generation. On-site power generation reduces power transmission losses and in the case of co-generation also supplies heat. Unfortunately, due to incomplete combustion within these engines the exhaust contains trace amount of hydrocarbons with up to $1000 \mathrm{ppm}$ of methane. Since methane has a greenhouse warming potential of about 20 to 50 times that of carbon dioxide, its emissions are becoming an area of concern. Although Denmark is the only jurisdiction with methane regulations today, it is likely that other jurisdictions will follow. Regulatory agencies are continually lowering emissions requirements on engines and methane emission standards are the next logical progression. Reliable cost-effective technology to combat methane emissions is not yet available but is highly desirable.

The most common technology for exhaust gas cleanup is a catalytic converter. In most applications, the converter would be installed downstream of the turbocharger where temperatures are typically below $500^{\circ} \mathrm{C}$. These temperatures are too low for achieving significant methane conversions with current oxidation catalyst technology. This paper will discuss a novel approach where the catalyst is installed upstream of the turbocharger where temperatures are $100-150^{\circ} \mathrm{C}$ higher. However, installing a catalyst upstream of a turbo presents other complications that will be addressed in this paper.

The literature reports many catalyst formulations that can be used for methane reduction [1-16]. Unfortunately there are none that can maintain their performance for more than a few hours of operation. Palladium based catalysts have been shown to give modest conversions $(\sim 30 \%)$ in the temperature region of typical natural gas exhaust $\left(\sim 400^{\circ} \mathrm{C}\right)[1,2,6,12,14]$. These catalysts show rapid performance deterioration caused by the small amount of sulphur present in the exhaust [1,2,6,7,12-15]. This performance loss is further aggravated by other 
components in the exhaust (i.e. water) $[2,5,6,12,14,15]$. Up to 50 to $80 \%$ reduction in performance have been reported.

Lean burn spark ignited engines can experience misfires due to ignition failure, flame quenching, and incomplete flame propagation [17]. This can lead to the catalyst being exposed to large concentrations of hydrocarbon during the misfiring event. In the pre-turbo position, temperatures are expected to be well above the catalyst light off temperature causing ignition of the excess fuel mixture. This could cause a rapid temperature rise across the catalyst leading to catalyst deactivation and/or catastrophic failure. This paper will discuss design issues and give suggestions for minimizing those risks.

\section{NOMENCLATURE}$$
\text { C }
$$

$C_{g, i}$ Gas concentration (mole fraction) of component $i$

$C_{p g} \quad$ Specific heat at constant pressure of gas $(\mathrm{J} / \mathrm{kg} / \mathrm{K})$

$C_{p s} \quad$ Specific heat of solid $(\mathrm{J} / \mathrm{kg} / \mathrm{K})$

$C_{O 2}$ Mole fraction of oxygen on catalyst surface

$C_{p_{t}}^{\gamma}$ Dimensionless empirical coefficient representing catalyst loading and activity

CPSI Cells per square inch

Ga Geometric surface area per unit substrate volume $\left(\mathrm{m}^{2} / \mathrm{m}^{3}\right)$.

$h$ Heat transfer coefficient $\left(\mathrm{J} / \mathrm{m}^{2} / \mathrm{s} / \mathrm{K}\right)$

$\Delta H \quad$ Heat of reaction $(\mathrm{J} / \mathrm{mol})$

$k^{i}$ Overall reaction rate term for component $i(\mathrm{~m} / \mathrm{s})$

$k_{c}^{i} \quad$ Mass transfer rate term for component $i(\mathrm{~m} / \mathrm{s})$

$k_{r}^{i} \quad$ Kinetic reaction rate term $(\mathrm{m} / \mathrm{s})$

$\dot{m}_{g} \quad$ Exhaust mass flow $(\mathrm{kg} / \mathrm{s})$

$M_{g}$ Molecular weight of exhaust $(\mathrm{kg} / \mathrm{kmol})$

$N_{\text {species }}$ Number of species

R Radius (m)

$S_{B E T} \quad$ Effective BET surface area $(\mathrm{m} 2 / \mathrm{g})$

$t \quad$ Time (s)
$T_{g} \quad$ Gas temperature $(\mathrm{K})$

$T_{S} \quad$ Solid temperature (K)

$v \quad$ Superficial velocity $(\mathrm{m} / \mathrm{s})$

Z. Axial distance (m).

\section{Greek symbols}

$$
\begin{array}{ll}
\mathcal{E} & \text { Void volume fraction } \\
\rho_{g} & \text { Gas density }\left(\mathrm{kg} / \mathrm{m}^{3}\right) \\
\rho_{s} & \text { Solid density }\left(\mathrm{kg} / \mathrm{m}^{3}\right) \\
\rho_{w c} & \text { Washcoat density }\left(\mathrm{kg} / \mathrm{m}^{3}\right) \\
\lambda_{s} & \text { Thermal conductivity of solid }(\mathrm{W} / \mathrm{mK}) \\
\eta & \text { Internal effectiveness factor }
\end{array}
$$

\section{Superscript}

\section{$\boldsymbol{n}$ Index of time step}

\section{Subscript}

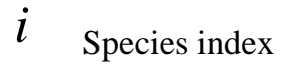

\section{EXPERIMENTAL METHODOLOGY:}

This study consists of two methods; first is the model gas reactor testing which simulates the actual conditions in the exhaust gas, and the second is computer simulations.

\section{Model Gas Reactor Testing}

Various catalysts were tested for their ability to completely oxidize methane to carbon dioxide and water under pseudo real life exhaust gas conditions. Exhaust gas conditions upstream of the turbocharger were simulated using a model gas reactor (Figure 1). Exhaust gas conditions and catalyst dimensions are presented in Table 1. A thermocouple was placed $1 \mathrm{~mm}$ away from the outlet of the catalyst. The temperature recorded by this thermocouple was taken as the reaction temperature. Four gases $\left(\mathrm{CH}_{4}, \mathrm{O}_{2}, \mathrm{SO}_{2}\right.$ and balance $\left.\mathrm{N}_{2}\right)$ were introduced to the reactor from four separate mass flow controllers. Prior to entering the reactor, the bulk-premixed gases were preheated to $130^{\circ} \mathrm{C}$. Water was added using a peristaltic pump after the preheater. The length of tube from the pre-heater to the reactor 
was heated to $130^{\circ} \mathrm{C}$ using heating tape to prevent condensation of the water. The tubing from the reactor to the gas chromatograph was heated to prevent water condensation. Gas pressure over the catalyst was controlled by restricting the flow through a valve installed downstream of the catalyst.

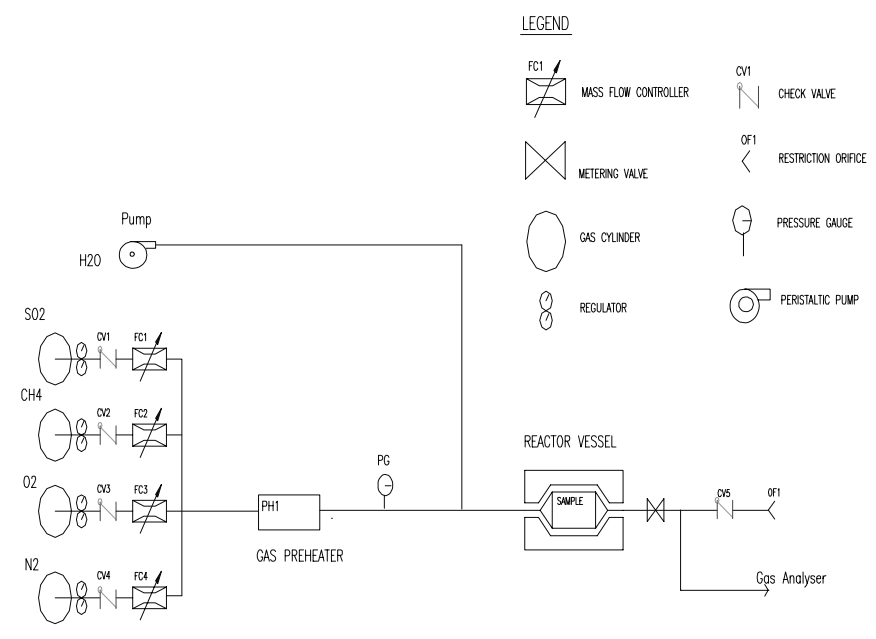

Figure 1: Flow Diagram of Model Gas Reactor

Table 1: Test conditions

\begin{tabular}{|l|l|l|}
\hline Catalyst Dimensions & $1 \mathrm{~cm}$ O.D. $x 5 \mathrm{~cm}$ long \\
\hline Space Velocity & $110,0001 / \mathrm{h}$ \\
\hline Gas composition & $\mathrm{CH}_{4}$ & $112 \mathrm{ppm}$ \\
\cline { 2 - 3 } & $\mathrm{H}_{2} \mathrm{O}$ & $6 \%$ \\
\cline { 2 - 3 } $\mathrm{O}_{2}$ & $10.8 \%$ \\
\cline { 2 - 3 } & $\mathrm{SO}_{2}$ & $5 \mathrm{ppm}$ \\
\cline { 2 - 3 } & $\mathrm{N}_{2}$ & Balance \\
\hline Temperature Range & $500^{\circ} \mathrm{C}$ to $560^{\circ} \mathrm{C}$ \\
\hline
\end{tabular}

Analysis was performed using a Varian CP-3800 Gas chromatograph (GC) equipped with an FID and TCD. The columns used on the GC for the separation are a CP-Sil 5CB, Hayesep T, Hayesep R and Molsieve 13X.

The catalyst formulations used in this study are listed in Table 2. Detailed preparation and composition information is not provided due to its confidential nature.

Table 2: Catalyst Compositions

\begin{tabular}{|l|l|}
\hline Catalyst A & $10 \mathrm{~g} / \mathrm{l} \mathrm{Pd} / \mathrm{Pt} 3: 1$ on $\mathrm{Al} 2 \mathrm{O} 3$ \\
\hline Catalyst B & $10 \mathrm{~g} / \mathrm{l} \mathrm{Pd}$ on $\mathrm{Al} 2 \mathrm{O} 3$ \\
\hline
\end{tabular}

\section{Computer Simulation}

A transient catalyst model is used based on the following assumptions:

- One dimensional "plug flow" monolith catalytic converter model

- Axial diffusion of mass and heat in the gas phase is neglected

- $\quad$ First order reaction rate (one step reaction)
- No interactions among pollutants

- Adiabatic conditions for the catalytic converter

As a simplifying assumption, surface reactions were not explicitly modeled, i.e. no surface reaction and no adsorption/desorption mechanisms were used. Instead surface reactions were bulked into a first order reaction kinetic term for each species. Laboratory experiments conducted by DCL indicated that kinetic rates could be adequately expressed as first order rates for the operating range studied.

The basic equations for the model consist of a mass balance for the gas phase (Equation 1), an energy balance for the gas phase (Equation 2), an energy balance for the solid phase (Equation 3 ), and a mass balance for the solid phase [18]. If first order reaction rates are assumed, then the explicit equation for mass balance in the solid phase can be eliminated and replaced with an overall reaction rate term $\left(\mathrm{k}^{\mathrm{i}}\right)$ (Equation 4$)$. For a given species the overall reaction rate term is determined from the bulked reaction rate taking place at the catalyst surface (the middle term of Equation 4) and the mass transfer rate of species from the bulk gas to the catalyst surface (the right-hand term of Equation 4). With oxygen in excess, the mole fraction of oxygen at the surface can be assumed the same as in the bulk gas. The heat transfer, mass transfer and kinetic rate expressions were developed by DCL from model gas reactor and engine test cell data.

To obtain the numerical solution, the length along the catalytic converter is divided into a number of longitude computational elements and the corresponding finite difference relations are approximated. As the first step the gas temperature is solved iteratively until convergence with the solution is achieved. Next the reaction rates are solved for each species using a fourth order Runge-Kutta method, and finally solid temperature is solved. This method normally achieves a solution in several minutes using a recent model desktop PC, allowing a number of design variations to be quickly assessed.

$\mathcal{E} \frac{\partial C_{g, i}}{\partial t}=-v \frac{\partial C_{g, i}}{\partial z}-k^{i} G a C_{g, i}, \quad i=1,2, \ldots, N_{\text {species }} \quad$ (Equation 1)
$\varepsilon \rho_{g} C_{p g} \frac{\partial T_{g}}{\partial t}=-v \rho_{g} C_{p g} \frac{\partial T_{g}}{\partial z}+h G a\left(T_{s}-T_{g}\right)$

(Equation 2)

$(1-\varepsilon) \rho_{s} C_{p s} \frac{\partial T_{s}}{\partial t}=\lambda_{s}(1-\varepsilon) \frac{\partial^{2} T_{s}}{\partial z^{2}}+h G a\left(T_{g}-T_{s}\right)$

$$
+\sum_{i=1}^{N_{\text {species }}}(-\Delta H)_{i} \frac{\dot{m}_{g}}{\pi R^{2} M_{g}} \frac{\partial C_{g, i}}{\partial z}
$$

(Equation 3)

The subscript $\mathrm{i}$ refers to the species $\mathrm{CO}, \mathrm{NO}, \mathrm{H}_{2}, \mathrm{CH}_{4}, \mathrm{C}_{2} \mathrm{H}_{4}$, $\mathrm{C}_{3} \mathrm{H}_{8}$ and $\mathrm{C}_{4} \mathrm{H}_{10}$. The overall reaction rate constant $\mathrm{k}$ is calculated by Equation 4. 


$$
\frac{1}{k^{i}}=\frac{1}{\eta C_{P t}^{\gamma} k_{r}^{i} \rho_{w c} S_{B E T} C_{o_{2}}}+\frac{1}{G a k_{c}^{i}} .
$$

\section{RESULTS AND DISCUSSION}

\section{Model Gas Reactor}

Catalysts described above were tested for their methane conversion efficiency in the pre and post-turbo position. These catalysts were aged using $\mathrm{SO}_{2}$ and water to deactivate the catalyst. In the pre-turbo position $\left(550^{\circ} \mathrm{C}, 2.6 \mathrm{bar}\right)$, it was found that the aged $\mathrm{Pd}$ catalyst reproduced results consistent with those in the literature [2,6,14]. Methane conversions of about $50 \%$ were achieved at the pre-turbo position (Figure 2). The Pd catalyst was then exposed to post-turbo conditions $\left(350^{\circ} \mathrm{C}, 1\right.$ bar) under the same mass flow conditions. The methane conversion decreased from $50 \%$ to approximately $5 \%$ in the post-turbo position. From these results, installing the catalyst upstream of the turbo is beneficial because of higher pressure and temperature.

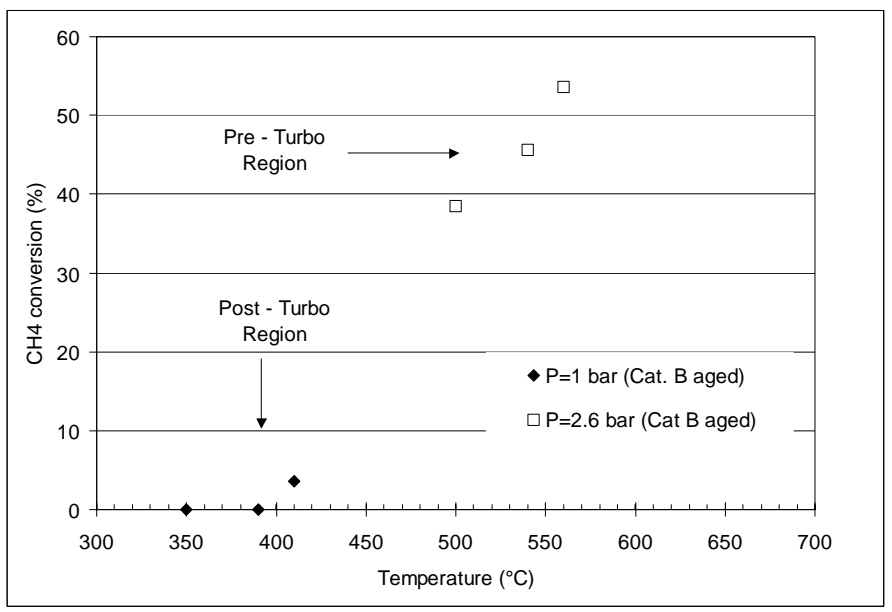

Figure 2: Influence of catalyst position on methane conversion (aged catalyst B)

Published results of McCormick and others [2,6,7,12-15] show that sulphur present in the exhaust stream in low concentrations of 1 ppm or less causes deactivation of Pd based catalysts. Our results confirm this finding. Figure 3 shows rapid deactivation of the Pd catalysts in this study after exposures of 12 hours to 5 ppm $\mathrm{S}$ in the gas stream. Methane conversions on catalyst $\mathrm{A}$ decrease from $90 \%$ to $55 \%$ and appear to plateau after 10 hours sulphur exposure. This is a result of $\mathrm{S}$ reacting with the surface of the $\mathrm{PdO}$ catalyst to form $\mathrm{PdSO}_{4}(2,6,12)$.

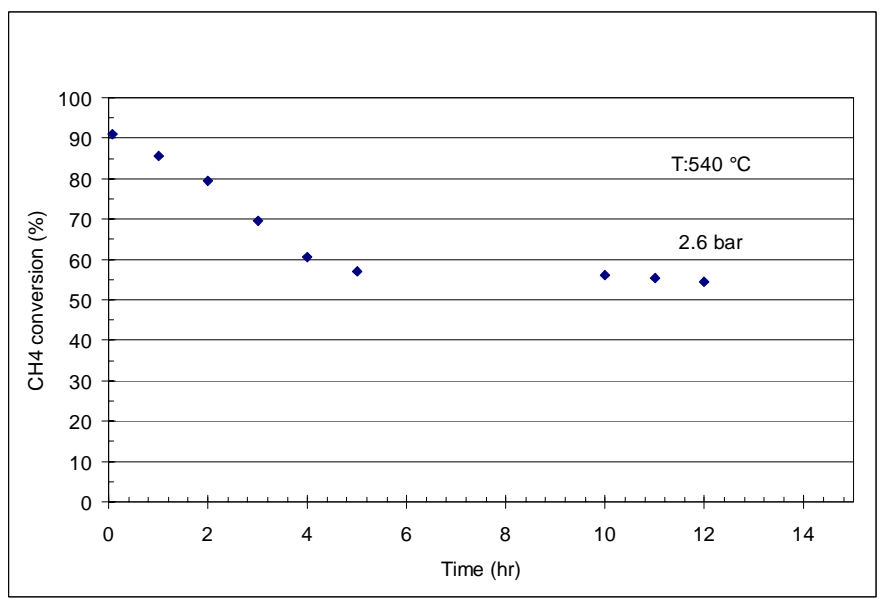

Figure 3: Aging of methane catalyst A with sulphur exposure

Misfiring events in natural gas engines are known to be frequent. During misfiring events, a pulse of a fuel rich mixture comes in contact with the catalyst. If sufficient energy is available this fuel mixture can ignite resulting in a large exotherm inside the catalyst. This exotherm can cause considerable amounts of damage to the catalyst. A rapid local temperature rise results from the hydrocarbon combustion may damage the catalyst through sintering of precious metal and the washcoat carrier. In extreme cases, the substrate can begin to melt or fracture and pieces can break off. In engines without a turbocharger this is not a significant problem since the fragments of the substrate would exit through the muffler or tail pipe. This is not the case with a catalyst installed upstream of the turbocharger. Dislodged fragments of the catalyst would encounter the precisely balanced blades of the turbocharger causing major failure.

\section{Computer Modeling}

In order to prevent the likelihood of this failure mode, a series of computer simulations were performed. These simulations helped to investigate different catalyst configurations to minimize the exotherm. The transient computer simulation is designed to mimic a misfiring event. During the first five seconds, the catalyst is exposed to normal operating conditions $\left(550^{\circ} \mathrm{C}, 2.5\right.$ bar, $\left.1000 \mathrm{ppm} \mathrm{CH}_{4}\right)$ where methane conversion is approximately $80 \%$ for a fresh, non-poisoned catalyst. At time equals five seconds, a pulse of $5 \%$ methane is entered in the model as illustrated in Figure 4. At time equals ten seconds, normal operation resumes. The length of misfiring event and methane conversion has been chosen arbitrarily as a reference case. As illustrated in Figure 4, the lower the cell density, the lower the maximum temperature will be, a result of lower conversions. 


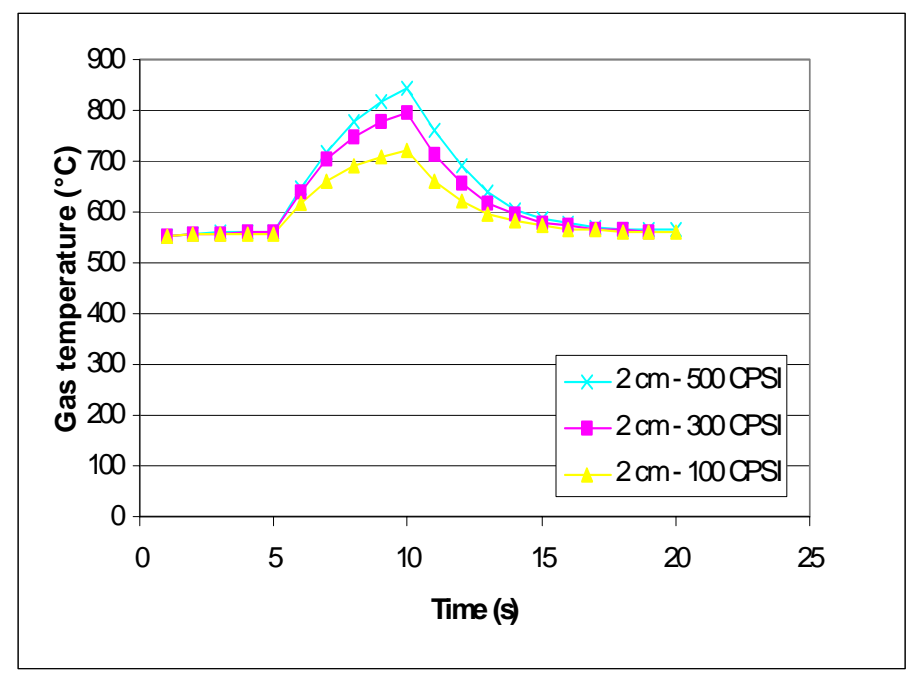

Figure 4: Influence of cell density on maximum temperature during misfiring event

Figure 5 shows the influence of catalyst length. In this case, the shorter the catalyst, the lower the maximum conversion will be. Since a shorter catalyst has a lower thermal mass, it warms up and cools down faster as illustrated in Figure 5. The benefit with a short catalyst is that it would be exposed to high temperatures for shorter periods of time. As a result, it is suggested to use a very short catalyst with a low cell density.

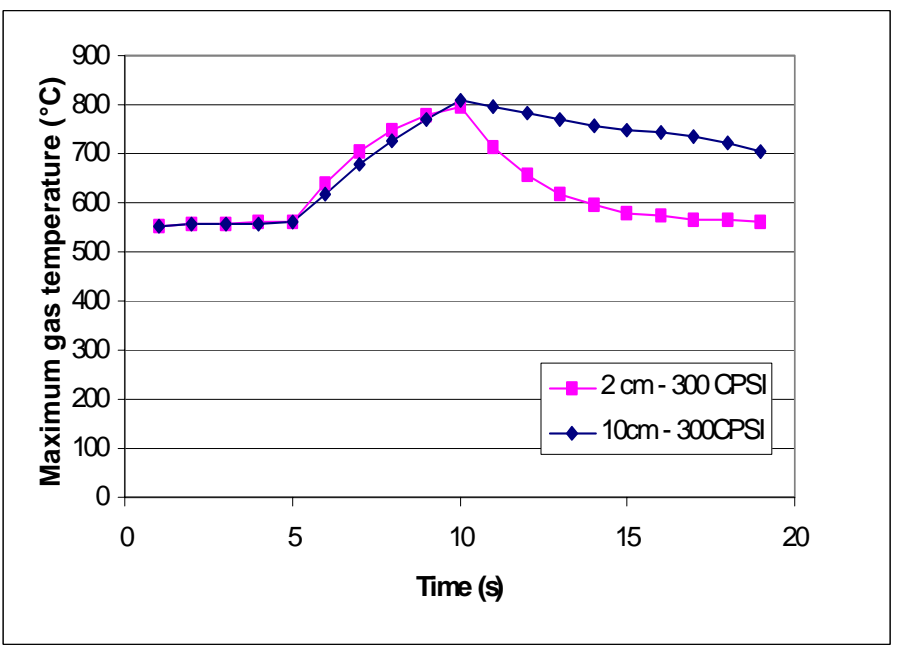

Figure 5: Influence of catalyst length on maximum temperature during misfiring event

The thermal management of catalyst outlet gas temperature can be optimized with the use of a cascade of catalysts in series instead of one single catalyst. For example, Figure 6 compares two scenarios, a single catalyst and a cascade of 3 catalysts in series representing the same total volume of catalyst. The catalysts are assembled together with an air gap between them so that there is no heat transfer by conduction between the catalysts. As illustrated in Figure 6, this yields a lowering of $25^{\circ} \mathrm{C}$ of maximum gas temperature before the turbo in this example.

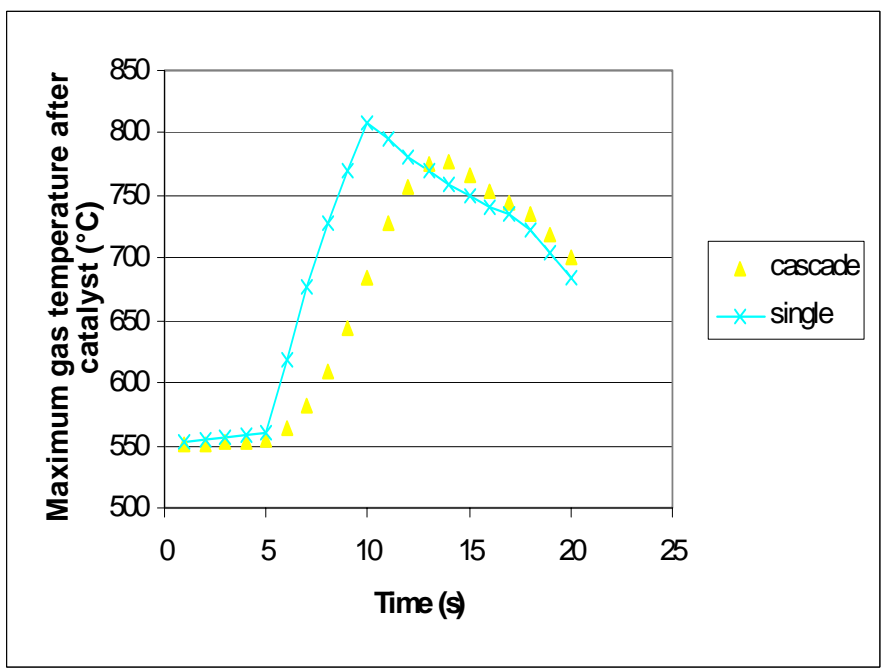

Figure 6: Thermal management through catalyst design

Figure 7 below shows the influence of the length of the misfiring event. As the duration of the misfiring event increases, the maximum temperature may reach unacceptable limits. Clearly, this demonstrates the need for controlling the misfiring events and stopping the engine after a certain period of time. By failing to control the misfiring, the engine manufacturer runs the risk of damaging the turbine blades because of excessive exhaust gas temperatures.

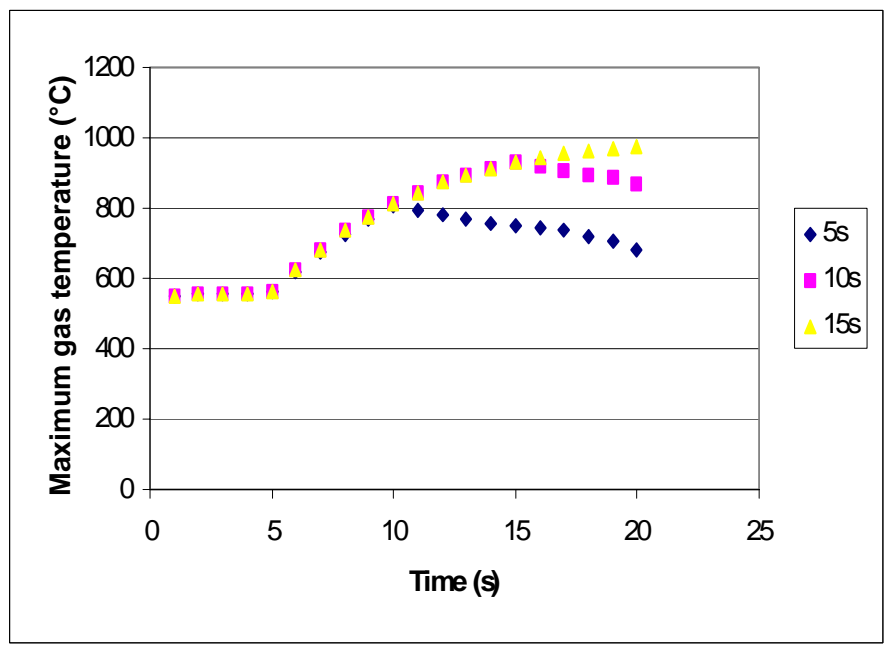

Figure 7: Influence of length of misfiring event

\section{CONCLUSION}

It has been shown in this paper that installing a catalyst upstream of a turbo is desirable for methane abatement. Overall methane conversion is significantly improved and can provide a greenhouse benefit with an appropriate catalyst. However, this creates additional design challenges of potential damages to the turbo. We have shown that through catalyst design; selecting a series of low cell density and short catalysts in series, the risk can be minimized. The final optimization of the catalyst system will depend on external factors such as turbine maximum 
operating temperatures, probable length of misfiring events, space constraint and catalyst technology.

\section{ACKNOWLEDGMENTS}

The authors would like to thank the following DCL employees. Darek Bialasz and Michal Huzij for their help during engine testing and catalyst preparation. We acknowledge the helpful advice of Karen Schrimer and John Muter.

\section{REFERENCES}

1) Centi, G., 2001, "Supported palladium catalysts in environmental catalytic technologies for gaseous emissions", J. of Molecular Catalysis A: Chemical, 173 287-312.

2) Mowery, D.L., Graboski, M.S., Ohno, T.R., McCormick, R.L., 1999, "Deactivation of $\mathrm{PdO}-\mathrm{Al}_{2} \mathrm{O}_{3}$ oxidation catalyst in lean-burn natural gas: aged catalyst characterization and studies of poisoning by $\mathrm{H}_{2} \mathrm{O}$ and $\mathrm{SO}_{2 "}$, Applied Catalysis B, 21,157-169.

3) Fujimoto, K., Ribeiro, F.H., Avalos-Borja, M., Iglesia, E., 1998, "Structure and Reactivity of $\mathrm{PdO}_{\mathrm{x}} / \mathrm{ZrO}_{2}$ catalysts for methane oxidation at low temperatures", J. of Catalysis, 179, 431-442.

4) Epling, W.S., Hoflund, G.B., 1999, "Catalytic oxidation of methane over $\mathrm{ZrO}_{2}$-supported Pd Catalysts", J. of Catalysis, 182 5-12.

5) van Giezen, J.C., van den Berg, F.R., Kleinen, J.L., van Dillen, A.J., Geus, J.W., 1999, "The effect of water on the activity of supported palladium catalysts in the catalytic combustion of methane", Catalysis Today, 41, 287-293.

6) Lambert, J.K., Kazi, M.S., Farrauto, R.J., 1997, "Palladium catalyst performance for methane emissions abatement from lean burn natural gas vehicles", Applied Catalysis B, $\mathbf{4}, 211-223$.

7) Yu, T-C., Shaw, H., 1998, "The effect of sulfur poisoning on methane oxidation over palladium supported on $\gamma$-alumina catalysts", 18 105-114.

8) Muller, C.A., Maciejewski, M., Koeppel, R. A. Baiker, A., 1999, "Combustion of methane over palladium/ zirconia: effect of Pd-particle size and role of lattice oxygen", Catalysis Today, 47, 245-252.

9) Muto, K., Katada, N., Niwa, M., 1996, "Complete oxidation of methane on supported palladium catalyst: Support effect”, A pplied Catalysis A, 134, 203-215.

10) Choudhary, T.V., Banerjee, S., Choudhary, V.R., 2002, "Catalysts for combustion of methane and lower alkanes", Applied Catalysis A: General, 234, 1-23.

11) Sekizawa, K., Widjaja, H., Maeda, S., O zawa, Y., Eguchi, K., 2000, "Low temperature oxidation of methane over $\mathrm{Pd}$ catalyst supported on metal oxides" Catalysis Today, 59, 69-74.

12) Lambert, J.K., Kazi, M.S., Farrauto, R.J., 1996, "Methane Emission Abatement form Lean Burn Natural Gas Vehicle Exhaust: Sulfur's Impact on Catalyst Performance", SAE 961971.

13) Kingstedt, F., Neyestanaki, A.K., Byggningsbacka, R., Lindfors, L-E., Lunden, M., Petersson, M., Tengstrom, P., Ollonqvist, T., Vayrynen, J., 2001, "Palladium based catalysts for exhaust after treatment of natural gas powered vehicles and biofuel combustion", Applied Catalyst A., 209, 301-316.

14) Mowery, D.L., McCormick, R.L., 2001, "D eactivation of alumina supported and unsupported $\mathrm{PdO}$ methane oxidation catalyst: the effect of water on sulfate poisoning", Applied Catalysis B, 34, 287-297.

15) Albers, P., Pietsch, J., Parker, S.F., 2001, "Poisoning and deactivation of palladium catalysts", J. of Molecular Catalysis. A : Chemical, 173 275-286.

16) Jang, B.W-L., Nelson, R.M., Spivey, J.J., Ocla, M., Oukaci, R., Marcelin G., 1999, "Catalytic oxidation of methane over hexaaluminates and hexaaluminatesupported Pd catalysts", Catalysis Today, 47, 103-113.

17) Badr, O., Alsayed, Manaf, M., 1998, "A parametric study on the lean misfiring and knocking limits of gas-fueled spark ignition engines", Applied Thermal Engineering, 18 579-594.

18) Oh, Se. H.; Cavendish, J.C., 1982, "Transients of Monolithic Catalytic Converters: Response to Step Changes in Feedstream Temperature as Related to Controlling Automobile Emissions", Ind. Eng. Chem. Prod. Res. Dev., 21, 29-37. 